\title{
Litigant Configurations: Turbulence and the Emergence of Complex Configurations
}

Scholars describe policy processes in the European Union (EU) as multileveled, networked, and fluid. As such, they typically involve a wide range of different actors, located at different governmental levels, whose interactions can feature cooperation but also conflict. Generally, political disputes over policy issues mobilize a fair number of actors from within the multilevel system whose relative positions, rivalries, and alliances come to form what we conceive as a policy conflict configuration. The emerging policy positions tend to be supported by several actors that may even unite into a coalition. Hence, far from being limited to a face-off between two actors, policy conflicts typically involve numerous stakeholders. While policy conflicts involve a large number of actors, the great majority of judicial conflicts do not. Most often, legal conflicts include only two parties: the applicant and the defendant. This is also true for EU annulment actions. Most of the conflicts discussed in Chapter 5 represent such a simple applicant-defendant configuration, as, for example, when Germany brought the Commission to court because of the Commission's interference with the German renewable energy law (T-134/14).

Even when more actors effectively have a stake in particular cases, the resulting litigant configuration in court does not always reflect that. This indicates that a filtering process from societal conflict to legal dispute must be at work (Glenn 1999). Two important structural aspects-in the sense of legal opportunity structures, as discussed in Chapter 3-work as

(C) The Author(s) 2020

C. Adam et al., Taking the EU to Court, Palgrave Studies in European Union Politics, https://doi.org/10.1007/978-3-030-21629-0_6 
enabling or constraining factors in this filtering process: actors' standing rights and their legal and financial resources. Simply put, not all interested actors are allowed to take on an active role before court even when they want to. Furthermore, not all actors are able or willing to invest the financial or legal resources necessary to take part in court proceedings, particularly when there are options for a free ride on the decision of other actors to go to court. Yet despite these factors discouraging interested actors from joining annulment cases, we do observe a substantial number of complex litigant configurations. In fact, while simple litigant configurations represent the majority of annulment cases, complex litigant configurations, in which additional litigants or defendants join cases, are far too frequent to be regarded as mere exceptions. Before this background, we set out to study simple and complex litigant configurations in this chapter. We will show that emerging conflict configurations can be linked to the motivations outlined in Chapter 5. The financial litigation motivation coins conflicts between member state governments and EU institutions and between national companies and the Commission. The institutional power motivation generally drives conflicts between member state governments and the EU, as well as between EU institutions among themselves. The ideological motivation is found in vertical conflicts between member states or non-governmental organizations and EU institutions, as well as among EU institutions. The political trust motivations generally underpin annulment actions, intervening as a two-level game where a national or regional government judicialises a conflict with an EU institution to send a positive signal to their constituency at home.

The specific link we explore in this chapter is the nexus between institutional turbulence and the emergence of complex litigant configurations. We propose in this regard that the emergence of complex litigant configurations is causally linked to institutional turbulence. Institutions are in turbulence when existing institutional arrangements are in flux, are new, or become unsettled. Annulment litigation that emerges in this context often involves more than just two actors. This is because the status quo ante of the turbulence represents a negotiated temporary equilibrium situation that tends to involve a substantial number of stakeholders. This temporary equilibrium comprises a financial dimension, an ideological dimension, an institutional or competence-related dimension, and a political or electoral dimension. Therefore, threats to disrupt the status quo hold the potential to trigger litigation decisions driven by 
all four motivations we described in Chapter 5. Moreover, institutional turbulence reduces legal certainty-an observation that can hardly be overestimated. In consequence, such turbulence makes the prospects of judicial success higher for potential litigants. Legal conflicts that involve fundamental struggles over the status quo that take place at such critical institutional and policy junctures are thus most likely cases that attract not only one but several actors and therefore reflect a more complex litigant configuration.

\section{Engaging With CompleXity}

In the previous chapter, we addressed the decisions of individual public actors to litigate. Now, we take a more macro-level perspective and focus on what we conceive of as litigation configurations. In annulment litigation, a diverse set of actors from various territorial levels can take part in lawsuits. We think of the possible combinations as configurations or constellations.

While litigant configurations differ enormously across annulment cases, we generally distinguish between simple and complex configurations based on the number of participants that take part in the case. Simply put, cases that involve only one applicant and one defendant are considered simple configurations. All other cases are complex configurations. Obviously, this is a simple distinction that lumps together various different alliances and cleavages. The following paragraphs intend to do justice to the various different constellations that make up the group of complex litigant configurations. With this, we hope to demonstrate that the distinction is conceptually and theoretically fruitful and empirically relevant.

In line with the distinction drawn between simple and complex conflicts (cf. Chapter 2), we speak about complex litigant configurations when at least three actors take an active role in the annulment litigation. One of these actors, the defendant, does not consciously choose to be involved; it has to defend itself as soon as a litigant decides to challenge one of its decisions. The crucial actor actually deciding to start a litigation is the applicant for an action for annulment. Additional parties can intervene either in favour of the applicant or in favour of the defendant. Actors on the applicant's side can also decide to raise an additional annulment action against that same EU measure that is already in force. Typically, the Court joins these cases under the umbrella of one 
proceeding and one judgement that binds together such cases against the same EU measure. Such joint cases thus reflect a complex litigant configuration.

Figure 6.1 provides an overview of the absolute number of annulment cases with a complex litigant configuration and of the share of complex cases (based on the total number of annulment cases). In total, we find 936 complex litigant configurations. Complex configurations reached a temporary peak relative to the absolute number of annulments in the mid-1990s. In absolute terms, the highest number of cases with complex litigant configurations emerged around a decade later, in the mid-2000s.

We discuss litigant configurations for vertical and horizontal conflicts separately. In the context of vertical annulment conflicts, we observe 828 complex litigant configurations. This amounts to about $26 \%$ of all vertical cases (see Table 6.1). Simple vertical constellations mostly include conflicts between individual private actors on the claimant side and the Commission or the Council on the defendant side. Yet they also often include individual member states litigating against the Commission.

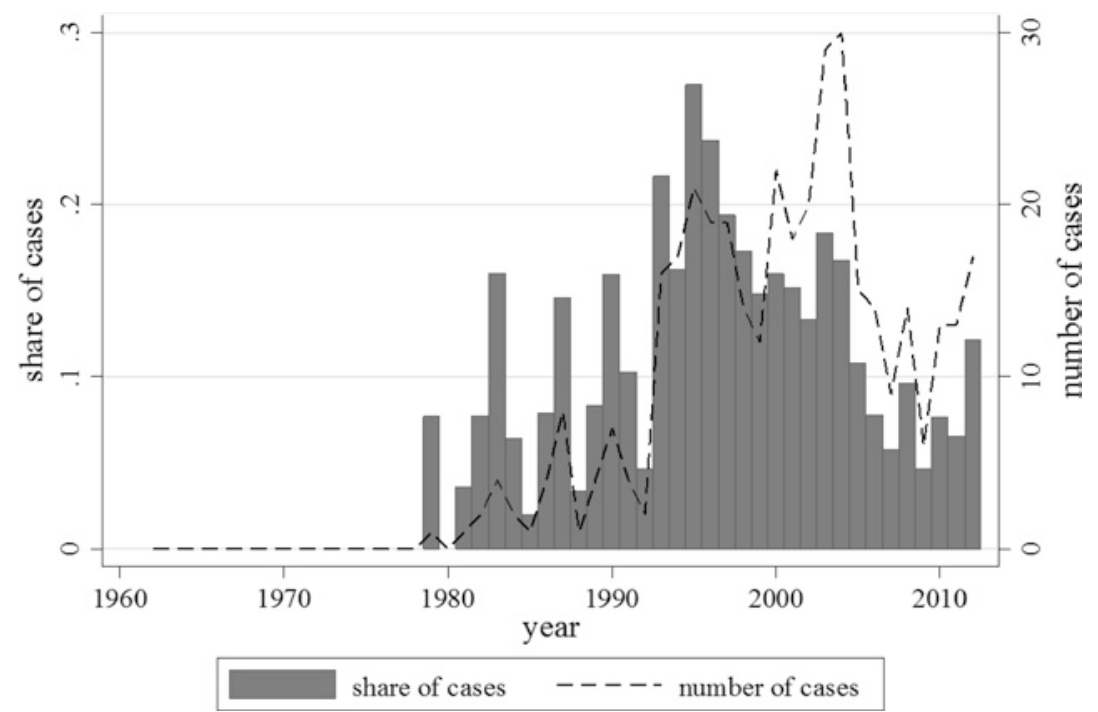

Fig. 6.1 Complex litigant configurations over time (Source Own data) 
The specific litigant arrangement in such vertical complex litigant configurations is quite diverse. Table 6.2 explicitly describes the five most frequent actor configurations that lead us to classify cases as complex vertical configurations. It is important to highlight that these configurations are not mutually exclusive as they refer to either the claimant or the defendant side. In 452 cases, we observe that several private actors joined forces on the claimant side of a conflict against the defending EU institution. In 158 cases, private actors and the Commission fought on the same side - the defendant side - of the conflict. Yet the Commission is supported as a defendant not only by private actors but also sometimes by one or several member state governments. We count 145 such constellations. As claimants, member states and private actors align in 155 cases and several member states align in 81 cases. While these configurations represent configurations that are rather numerous, another 155 cases remain; these belong to other complex litigant configurations, not explicitly referenced here. In any case, the purpose of this section is to provide a condensed insight into the complexity and diversity of actor configurations in annulment conflict rather than to provide a detailed data report.

Turning to horizontal annulment conflicts, it is important to note that in relative terms, complex litigant configurations are more frequent here. While we classify only twenty-six horizontal conflicts as cases with simple litigant configurations, 108 of these cases feature a complex

Table 6.1 Simple and complex cases in vertical conflicts (1957-2012)

\begin{tabular}{ll}
\hline Type of legal conflict & Frequency \\
\hline Simple vertical conflicts & 2254 \\
Complex vertical conflicts & 828 \\
\hline
\end{tabular}

Source Own data

\begin{tabular}{ll}
\hline Complex configurations & Frequency \\
\hline Private + Private & 452 \\
Commission + Private (defendants) & 158 \\
Commission + MS (defendants) & 145 \\
MS + Private & 155 \\
MS + MS & 81 \\
Other configurations & 155 \\
\hline
\end{tabular}

Source Own data. $\mathrm{MS}=$ member state
Table 6.2 Most frequent complex actors' configurations in vertical conflicts (1957-2012) 
configuration. This amounts to about $81 \%$ of all horizontal cases. Complex configurations are thus the norm rather than the exception for horizontal conflicts (see Table 6.3).

Most often, these complex horizontal configurations consist of the cases in which the Council and one or several member states join forces (on either side of the conflict). We find this configuration forty-nine times. In thirty-one cases, the Commission and member states fought on the same side, while the Commission and the European Parliament (EP) did so seventeen times. Again, we include a catch-the-rest category for other configurations that turn fifteen cases into complex cases. It is important to highlight that, as for vertical constellations, these horizontal configurations are not mutually exclusive. So one annulment conflict can feature, for example, the Commission and the EP on one side and the Council and member states on the other side. Similarly, the same annulment conflict can feature the Council and some member states on one side versus the Commission and other member states on the other side (Table 6.4).

Overall, we see that in relative terms, complex litigant configurations are more frequent in the context of horizontal conflicts than in vertical conflicts. However, even among vertical conflicts, complex configurations can hardly be treated as a phenomenon of marginal empirical relevance. Complex litigant configurations come in many forms and emerge in different contexts. While it is difficult to determine precisely whether a specific case will give rise to a complex litigant configuration, we argue that the emergence of complex configurations is far from random.

Table 6.3 Simple and complex cases in horizontal conflicts (1957-2012)

\begin{tabular}{ll}
\hline Type of legal conflict & Frequency \\
\hline Simple horizontal conflicts & 26 \\
Complex horizontal conflicts & 108 \\
\hline
\end{tabular}

Source Own data
Table 6.4 The Council and the Commission in complex configurations (1957-2012)

\begin{tabular}{ll}
\hline Complex configuration & Frequency \\
\hline Council + MS & 49 \\
Commission + MS & 31 \\
Commission + EP & 17 \\
Other configurations & 15
\end{tabular}

Source Own data. $\mathrm{MS}=$ member state 


\section{Theorizing Complex Litigant Configurations}

Unfortunately, extant research has so far not provided much insight regarding the factors that shape litigant configurations. Typically, litigant configurations are treated as exogenous factors that potentially influence judicial decisions. Legal scholars do so when studying amicus curiae $^{1}$ briefs before national courts to learn about supporters and their arguments in court. The question in this context is whether litigants supported by (legally) powerful amici have a greater chance of success; although the empirical validity of this assumption is debated (Sheehan et al. 1992).

Political scientists take a similar approach when they analyse how litigant configurations correlate with Court of Justice of the European Union (CJEU) decisions to assess the Court's independence (e.g. Carrubba et al. 2008, 2012; Larsson and Naurin 2016). Again, this approach starts with different litigant configurations as exogenous factors. On this basis, scholars assess how the Court responds to them. Does the Court tailor its rulings to the political power that backs up either side of the dispute or is it immune to such political pressures? This way of using litigant configurations does not explicitly theorize the emergence of different litigant configurations. And yet it rests on the assumption that actors participate because they have a stake in the legal conflict they join. This is why they reveal their preferences to the Court. While we are far from challenging this assumption, we try in this chapter-and throughout this book more generally-to complement and qualify the underlying assumption in several regards.

First, Chapter 5 has laid out that there are different motivations for taking an active role in court proceedings. Winning the imminent legal case is not always important for this decision. While some actors might have a financial stake in a case, the same case might be of electoral relevance to other actors. Ideological or policy goals, institutional competence-related stakes, material or financial stakes, political trust, and electoral stakes can all cause actors to take an active role in court proceedings. In fact, we assume that motivations are particularly heterogeneous in conflicts characterized by complex constellations. It seems overly rigid to assume that all parties involved share the same motivation. This flows from our argumentation above. Developing the different motivations, we highlighted that frequently, a specific motivation is typical for one category of actors but not for another. For example, we 
expect private actors to be motivated by material gains in most cases. Political trust, in the form of electoral gains, in turn, is likely to motivate actors that compete for votes at the ballot box. As the tables above show, complex conflicts regularly involve different types of actors and constellations. Thus, they are likely to comprise different motivations for conflicts and objectives when going to court, too.

Second, it would be a mistake, however, to exclusively focus on these motivations and overlook the legal merits of the case. This might be obvious to legal scholars. Rather strikingly, however, this constraint seems too often to escape the eye of political scientists. Social movement research has highlighted that legal claims cannot be based on just any argument when going to court. After all, bad and clearly invalid legal arguments will maximize the chances of legal defeat that can seriously hurt actors' long-term interests. Rather, available precedent or statutory basis on which the case can be argued is crucial (Andersen 2005). Here, analytically, the legal stock is a structural factor that influences litigation decisions (Vanhala 2011). However, the impact of this is typically discussed within extant research at the level of single cases rather than as a systematic factor. In the aforementioned studies that focus on the correlation between actor configurations and CJEU decisions (e.g. Carrubba et al. 2008, 2012), analyses do not control for the legal merits of a case or plea. Obviously, this would be rather difficult to do. But without doing so, we cannot account for the empirical fact that certain cases are more likely to be won in court than others merely because of the different legal merits of the cases. Yet what if the legal merits of a case should tend to spur different kinds of litigant configurations? Would we not always run the risk of mistaking correlations between litigant configurations and legal outcomes for causal impacts of litigant configurations on judicial behaviour?

As Chapter 5 on motivations has laid out extensively, very different motivations can bring actors to litigate. At the same time, our interviews highlighted that actors systematically consider the legal merits of a case. Before a decision to go to court is taken, they make an analysis of the situation by considering whether "we have a chance to succeed "yes/ no", or to what extend do we technically speaking recommend to [go to court] "yes/no" (EP_l, cf. also COM_1, CONS_l, MIN_DE_1, MIN_ES_4, MIN_ES_5). Thus, while actors might be motivated differently, they are always constrained or enabled by the legal merits of a case. In a logical extension from the arguments presented in Chapter 5 on the 
motivations of individual actors, complex litigant configurations are thus the result of several actors having a stake in the case and perceiving the legal situation - at the very least - to be sufficiently unclear as to be willing to go to court.

Obviously, this general condition can and does arise in various contexts. It is, however, most likely to emerge in situations that we choose to describe as situations of institutional turbulence. With this emphasis of turbulence, we make use of a concept from the context of organizational research. Here, turbulence is used to describe situations when organizations are facing changes that 'are nontrivial, rapid, and discontinuous' (Cameron et al. 1987, 225). Often, the term turbulence is also used to describe situations of uncertainty (Burns and Stalker 1961) or as a direct consequence of organizational change (Cameron et al. 1987; Ansell et al. 2017; Trondal and Bauer 2017).

Turbulence thus refers to a situational context that lacks clarity, routine, and certainty. These situations are likely to threaten established policy paradigms, legal interpretations, implementation practices, competence distributions, political alliances, or resource allocations. Situations of institutional turbulence are situations that apply beyond individual interests. They alter the setting for many actors at a given point in time; in other words, the situation provides supranational, national, or subnational actors with ideas about why annulments might further theirpossibly differing-stakes. When this is the case, many different actors are likely to have a particular stake in overturning or consolidating the legality of a specific legal act. Institutional turbulence can thus be the result of treaty or policy changes. Historical institutionalists describe situations that can fundamentally alter the path of law and public policy as critical junctures (Hall and Taylor 1996). Institutional turbulence is a typical result when such path changes are adopted. They represent a divergence from the status quo by changing interpretations, introducing new legal concepts for the first time, abolishing old rules, or changing the competence structure.

Supranational acts can be the source of institutional turbulence. We find several different empirical manifestations of which we highlight the three most obvious in the following. First, a treaty change clearly represents a time of substantial institutional turbulence. Assuming that with the entering into force of a treaty change, all uncertainties would vanish neglects that treaties consist of rather abstract terms and rules that require further interpretation to come to life. Treaties are always 
incomplete contracts. Second, treaty change is not the only trigger of institutional turbulence; sector specific policy reforms, typically shifting the underlying logic of a number of different policy instruments and practices, can also be at the origin of turbulences. Such reforms sometimes even come in the form of soft law (Terpan 2015). The adoption of a new state aid action plan, new guidelines on merger control, or new rules on funding the common agricultural policy can represent similar threats or disruptions of the status quo, which in turn will generate critics and proponents and will come with a non-negligible amount of legal vulnerability that can be exploited in court. Third, even individual decisions create institutional turbulences. Consider a Commission decision that changes the standards for assessing particular issues, as was the case when the Commission declared illegal state aid to ProSiebenSatl and the RTL Group, two private broadcasting companies. ${ }^{2}$ That decision, meant as a particular intervention, turned out to be a critical juncture in the Commission's way of assessing the legality of state aid. ${ }^{3}$

We argue that supranational acts causing situations of institutional turbulence are particularly likely to lead to complex litigation patterns. These situations are likely to both yield high stakes for several actors and to create sufficient legal uncertainty to encourage these different actors to try their luck in court. First, whenever the status quo is disrupted, protest and support by several actors, which act upon different motivations, are likely to emerge. The status quo represents equilibrium on several dimensions simultaneously; it consists of a situation of stability on the financial, institutional, ideological, and political fronts. Consequently, disrupting the status quo implies bringing about important changes on most (if not all) of these dimensions simultaneously. While some actors may be reactive to a disruption in a financial situation, others might rather be sensitive to the institutional or political dimension of the disruption. Hence, institutional disruption is likely to affect different types of actors, each of whose reasons for considering raising annulment actions may be different. Likewise, institutional disruption opens an opportunity for other actors (the losers of the status quo that is being disrupted) that may want to intervene in support of the defendant to prevent a return to the status quo ante. Here again, several dimensions (financial, institutional, ideological, political) are at stake simultaneously. Hence, such situations are particularly likely to see the engagement of different types of actors, creating a multi-actor defending front before the Court. 
Furthermore, institutional turbulence creates legal uncertainty. When a supranational act is aligned with the corresponding policy or institutional path, its legality has typically already stood the test of time and the review by courts. Schmidt (2012) refers to this as the path dependency of case law. Following a functionalist argument, she shows that litigants transfer legal arguments from one case to the next or even from one policy area to the next. This creates a positive feedback loop that paves the trajectory of case law. Legal certainty in such contexts of continuity is relatively high. Put differently, in stable situations, a case is more likely to be clear-cut, and an actor can more easily assess its chance of succeeding by simply applying path dependent reasoning. By contrast, institutional turbulence on these various levels creates legal uncertainty. When a supranational act represents a critical juncture in policy or institutional terms, the result of its adjudication by the Court is an open question. If the supranational act is exploring new territory, the existing legal stock does not allow predicting with relative certainty how the Court will assess it. Chances of success are thus significantly higher for litigants against supranational acts disrupting the status quo than against supranational acts reinforcing an existing policy or institutional path that has been previously adjudicated by the Court. Higher chances of success should therefore, logically, attract a higher number of litigants, which, in turn, makes complex litigant configurations a more likely outcome.

\section{Complex Litigant Patterns in the Face of Institutional Turbulence}

To assess the plausibility of this link between institutional turbulence and the emergence of complex litigant patterns, we proceed in several steps. In the context of an initial correlational analysis, we start from the emergence of institutional turbulence in the form of treaty reforms and assess the relative frequency of complex litigant configurations. In a second step, we turn to qualitative case analyses. Here, we start from the observation of complex litigant configurations and try to trace them back to instances of institutional turbulence.

In our conceptualization, treaty changes represent instances of substantial institutional turbulence. By adjusting the distribution of competences within the EU system, or better within the EU's different policy systems, they essentially change the rules according to which 
actors interact: treaty changes thus alter the games that actors play. As such, treaty changes create the opportunity to alter established routines of interactions and change the substance of public policy. Elsewhere, we have described this mechanism in more detail (Bauer and Hartlapp 2010). The argument is that the modification of treaty provisions invites supranational actors to engage in attempts to actively stretch their competences, since the amendment of existing treaty provisions or the adoption of new rules often results in formal compromises and ambiguous wording, giving rise to legal uncertainty. Presuming the interest of the Commission and other EU institutions for that matter, 'to extend its powers, it might be inclined to use these situations of legal flux for testing out supranational room for manoeuvre (Bauer and Hartlapp 2010). These are moments of institutional turbulence, where old equilibria arrangements - in terms of resource allocation, competence allocation, ideology, etc.- - are substantially threatened without having settled on any new specific equilibrium. 'The concrete balancing of interests and legal interpretations invites a tug-of-war' (Bauer and Hartlapp 2010, 209). Rather than strictly setting a new path for policy development, treaty modifications thus represent critical institutional and policy junctures. The trajectory that policies will take from there will be subject to conflict.

As we have laid out in detail in Chapter 5 , there are different motivations for initiating annulment litigation against such attempts to shape new institutional or policy trajectories. The motivation to protect decision-making competences is just one of them. Trying to avoid a certain policy trajectory implied by supranational legal acts taken at such critical junctures can also be ideologically, financially, or electorally motivated, where political trust depends on entering into conflict. This is why situations of institutional turbulence that represent critical policy junctures are most likely situations for complex litigant configurations to occur. In combination with the legal flux (Bauer and Hartlapp 2010), which is a typical feature at critical junctures after larger institutional or policy modifications, many actors might be motivated not only to litigate. They are also likely to perceive the legal situation as sufficiently unclear to allow for litigation. Legal defeat against the EU institution in these situations does not seem to be inevitable. Consequently, the probability that several actors will engage in annulment litigation and will not shy away from the Court, because the matter is too important-again, financially, ideologically, electorally, or in terms of competences-and is not legally 
discouraging per se, creates a most likely situation for complex litigant configurations to emerge.

One of the consequences of this effect of institutional modification is that we see a significantly elevated share of complex litigant configurations in the year in which treaty changes enter into force as compared to all other years. Table 6.5 presents the results of an independent-samples $t$-test to compare the share of complex litigant configurations of all annulment conflicts per year in which the case was launched, between years in which treaty changes went into effect and years without such an event. For years with treaty modifications entering into force, we observe an average of $15 \%$ of annulment conflicts featuring a complex litigant configuration where we observe only an average of around $7 \%$ for years without such events. This difference is statistically significant at the $5 \%$ level. All treaty modifications from the Single European Act, the Maastricht Treaty, the Amsterdam Treaty, the Nice Treaty, to the Lisbon Treaty are included as treaty modifications. Instead of using the year of ratification, we use the year of entering into force to capture their effects.

While these results help to support our argument, we do not want to rely solely on this group comparison. On the one hand, the rather large difference in means is partly the result of the fact that complex litigant configurations were absent or very rare before the 1980s, a time for which we included no (major) treaty modifications. While this does correspond to our general argument, the average shares between both groups move much closer together if we exclude the years before the 1980 s for the purposes of a robustness check. With $15 \%$ versus $10 \%$, the treaty modification years still display a higher share of complex litigant configurations. However, the standard deviation is somewhat higher and

Table 6.5 T-test on the relative frequency of complex litigant configurations in years with and without treaty changes

\begin{tabular}{|c|c|c|c|c|c|}
\hline & \multicolumn{2}{|c|}{$\begin{array}{l}\text { Year without } \\
\text { treaty change }\end{array}$} & \multicolumn{2}{|c|}{$\begin{array}{l}\text { Year with } \\
\text { treaty change }\end{array}$} & \multirow[b]{2}{*}{$\mathrm{T}$-test } \\
\hline & Mean & $S D$ & Mean & $S D$ & \\
\hline $\begin{array}{l}\text { Share of complex } \\
\text { annulment cases }\end{array}$ & 0.07 & 0.01 & 0.15 & 0.03 & $-2.27^{*}$ \\
\hline
\end{tabular}

Note ${ }^{*} p<0.05 ; N=51$; the share of complex cases is measures as a fraction between a minimum of 0 and a maximum of 1

Source Own data 
thus the difference does not quite make it over the typically accepted threshold for statistical significance. Therefore, we seek to substantiate our argument through case study evidence that allows tracing the causality underlying this correlation of treaty change and complex constellations in a more nuanced way.

The annulment case Commission v. Council (C-114/12) serves as a first illustration. Here we see how treaty changes create institutional turbulence that leads to attempts to stretch and specify new competences and ultimately promote complex litigant configurations. One of the many modifications that came with the Treaty of Lisbon was a clarification of the EU's competences in external affairs. The treaty added Article $3(2)$ to the Treaty on the Functioning of the European Union (TFEU). This article stipulates that the EU has exclusive competence to conclude an international agreement where 'its conclusion is provided for in a legislative act of the Union or is necessary to enable the Union to exercise its internal competence, or in so far as its conclusion may affect common rules or alter their scope' (Woods and Peers 2014).

While Article 3(2) TFEU seemed to strengthen the EU's competences to conclude international agreements, it remained to be seen how this provision would affect the actual conclusion of such agreements in practice. This became clear in 2011 when the Council of Europe set out to update regulations on neighbouring rights for broadcasting organizations and was looking for negotiation partners in the EU. While the Commission submitted a decision proposal to the Council that would delegate the negotiation of this agreement to the Commission, member states in the Council were rather reluctant to delegate this task fully. Instead, they adopted a decision that would authorize the Commission 'to participate, on behalf of the Union, in the negotiations for a Convention of the Council of Europe'. At the same time, however, they declared that 'the member states should participate on their own behalf' (CJEU 2014, para. 32). While this latter provision was clearly confined to 'matters that arise in the course of the negotiations that fall within their competence' (CJEU 2014, para. 32), the overall approach of trying to establish a shared role in the negotiations can be interpreted as a quite restrictive application of Article 3(2) TFEU. Even more so, in an attempt to limit the Commission's freedom in these negotiations, the decision foresaw that 'to ensuring the unity of the external representation of the Union, the Member States and the Commission should cooperate closely during the negotiation process' (CJEU 2014, para. 32). 
After all, neighbouring rights had become a sensitive political issue in several member states. Generally, neighbouring rights are similar to copyright laws in that they regulate how much broadcasting organizations have to pay for playing music. Yet instead of regulating how much money copyright holders obtain, they regulate how much money music labels, producers, and performers get. Such neighbouring rights have gained a special place in the Commission's Digital Single Market Strategy. News publishers have found it increasingly difficult to collect revenue for the content they create. Print subscriptions have been going down and advertising income has followed suit. While many news publishers put a lot of hope in online advertising revenue from their websites, so called news aggregators such as Google News have become a serious threat since they collect and gather snippets of content from publisher's websites and draw a lot of consumer traffic without paying for displaying the content provided.

Different member states eventually took different steps to approach this issue. In 2012, Belgium, for example, settled with Google in a bilateral agreement. According to this agreement, Belgium abstained from passing legislation that would force Google to pay for services to publishers in exchange for a commitment by Google to partner with publishers and help them to increase their revenues via implementing Google+social tools, including video Hangouts, on news sites, and launching official YouTube channels' (Geerts 2012; Rosati 2016). France quickly followed to strike a very similar deal in 2013, in which Google agreed to create a sixty million euros Digital Publishing Innovation Fund and reinforce its previous commitments in France, such as the Google Cultural Institute in Paris (Rosati 2016). Germany, in contrast, took a more adversarial approach by adopting a law that would allow publishers to charge Google for using their content (Rosati 2016).

The Council's (partial) delegation to negotiate an agreement on these and other related issues of cross-border publishing and broadcasting preceded these national responses. Member states had not yet adopted these approaches but were still in the process of formulating national responses. Therefore, they were reluctant to have the Commission tie their hands regarding national broadcasting policies by setting an unwanted legal frame in the negotiations with the Council of Europe. The Commission, however, strongly opposed this reluctance on the side of the member states and demanded full responsibility and competence. The resulting annulment conflict initiated by the Commission against the Council's decisions to secure a strong place for member 
state governments in these negotiations represented the 'first case in which the Court interpreted Article 3(2) TFEU added by the Treaty of Lisbon' (Woods and Peers 2014). While the Lisbon Treaty modified the rules, there remained substantial conflict between member states in the Council and the Commission over how this would affect the gameparticularly in this specific situation. This first Court ruling on this newly added article thus represented a critical juncture in terms of clarifying (1) future competences in the negotiation of international agreements and (2) in terms of the specific negotiation of neighbouring rights for broadcasters.

In line with the arguments presented above, and in awareness of the relevance of such critical junctures, several member states joined the case-all in support of the defending Council-as did the EP in support of the applying Commission. Specifically, the eventual litigant configuration included the EP and the Commission on one side, and the Council and the German, Dutch, Polish, Czech, and United Kingdom governments on the other side. Since this was the first time the Court had to interpret the specific meaning of Article 3(2) TFEU, it seems fair to say that the Court's eventual decision was far from obvious. Particularly contested was the question of whether this specific international agreement fell under Article 3(2) TFEU at all. The defendants contested the claim that existing EU legislation even covered the substance of the agreement. While several EU directives-such as the Council's Satellite and Cable Directive No. 93/83/EEC ${ }^{4}$ —dealt with cross-border publishing, they were formulated with respect to specific technologies and created uncertainties with respect to the applicability for internet-based services (Woods and Peers 2014). Overall, the case thus nicely illustrates the link between treaty changes, institutional turbulence in specific policy sectors, and the resulting incentives for many actors to take an active role in annulment litigation at such critical policy junctures. In this case, the EP as well as several member state governments were motivated by the struggle over the future competence distribution and encouraged to litigate by the uncertainty characterizing the legal situation.

Obviously, however, treaty modifications are only one potential source of institutional turbulence in different policy fields. This plausibility probe thus only relates to one aspect of our argument. While treaty changes do represent large disruptions of the status quo and do imply subsequent struggles over the materialization of these treaty changes in specific alterations of existing policies, institutional turbulence manifests itself in smaller scale and more regular actions, too. 


\section{The Expanded Tobacco Case (T-170/03)}

Manifestations of the mechanism at a smaller scale can be illustrated with the help of case T-170/03 dealing with expanded tobacco products. In this particular case, the established policy equilibrium was not dissolved through a treaty modification. Instead, the Commission created institutional turbulence by considering modifying the application of Council Directive 95/59/EC on Manufactured Tobacco. ${ }^{5}$ Whereas the Commission had traditionally classified expanded tobacco as 'manufactured tobacco other than smoking tobacco', ${ }^{6}$ it decided within its comitology system to reclassify expanded tobacco and henceforth treat it as smoking tobacco, in line with Article 5(1) of the Council Directive 95/59/EC on Manufactured Tobacco.

Tobacco refers to a processed form of tobacco. The producer British American Tobacco compared this process with the process for making puffed rice snack food; specifically, the process to make dry ice expanded tobacco 'involves permeating the tobacco leaf structure with liquid carbon dioxide before warming. The resulting carbon dioxide gas forces the tobacco to expand' (British American Tobacco 2014). Expanded tobacco has become a popular product among producers and customers because it helps both groups save costs. Essentially, it allows producers to buy fewer tobacco leaves for the same number of rolled cigarettes. Furthermore, when sold as roll-your-own tobacco, its greater volume at lighter weight produces a tax advantage for customers, who are able to roll just as many cigarettes (due to greater volume) with a lighter pack of tobacco, which is taxed (typically to a substantial part) based on its weight (Canadian Coalition for Action on Tobacco 2004). Because of these characteristics, expanded tobacco has carried the hopes of the tobacco industry, which hoped that 'by offering customers expanded tobacco in our cut filler products, we will continue to grow our business in the face of continuing governmental regulations and higher excise taxes' (Miller 2013).

This reclassification essentially meant two things. First, it meant that expanded tobacco was now subject to excise duties (CJEU 2001, para. 8). According to Commission Regulation (EEC) No. 3311/86, expanded tobacco was considered unsuitable for smoking without further industrial processing. In Article $11(\mathrm{~d})$ of Directive $95 / 59 / \mathrm{EC}$, the Commission explicitly excluded tobacco products from excise duties 'if it was reworked by the producer'. Now expanded tobacco would be treated under the category of smoking tobacco subject to excise taxes. 
Second, as a result of this classification, the transporting and trading of expanded tobacco was now subject to stricter administrative requirements. These requirements were specified in Article 18(1) of Council Directive 92/12/EEC. ${ }^{7}$ Most importantly, any shipment of expanded tobacco would now always include an enclosed document. The directive did not specify this document any further and merely stated that this could be an administrative or commercial document and that the Excise Duties Committee would specify its form and content. Generally speaking, the system was, however, the paper-based precursor to today's Electronic Excise Movement and Control System, which is now able in real-time to monitor the movement of products for which excise taxes still have to be paid.

As one of the main exporters of expanded tobacco from the United Kingdom to other EU member states, the private company British American Tobacco requested to see the minutes of the respective comitology deliberations underlying this reclassification. When the Commission denied this access to the respective internal document, British American Tobacco initiated an action for annulment against the Commission (T-170/03 but also T-111/00). Essentially, the company claimed that denying this request violated the common code of conduct concerning public access to internal documents adopted in $1993 .{ }^{8}$ For the company, it would be essential to know exactly which member state delegates argued for and against the reclassification and why. This knowledge would facilitate its interactions with national customs authorities, which were necessary to minimize the administrative burden and legal uncertainty associated with expanded tobacco exports. While excise duties were harmonized to some degree among member states, 'there remain significant differences in the treatment of expanded tobacco by the various customs authorities of the member states, and this causes the applicant difficulty' (CJEU 2001, para. 27). Therefore, it would be essential to know exactly the positions of the respective member states on how they would handle expanded tobacco under the national excise duty regime.

In fact, the differential and complex handling of expanded tobacco as a specific tobacco product continues to be an issue to this day. In 2012, a study conducted by Ramboll Management and Europe Economics still discussed the administrative burden involved in the movement of expanded tobacco as an intermediary product that is hard to verify 
between member states (Pedersen et al. 2012, 171). In terms of the motivations for engaging in the respective conflict, it seems clear that British American Tobacco as exporter of the respective good was driven by financial concerns resulting from the subjection to excise duties and from the administrative burden that came with it in different national contexts.

Importantly, however, this conflict also triggered litigation by other actors for different motivations. Specifically, the governments of Denmark and Sweden, as well as the European Data Protection Supervisor, joined British American Tobacco. The case thus clearly comprises a more complex litigant structure than a bilateral face-off between British American Tobacco and the Commission. Our argument about the tendency of institutional turbulence to engage actors with very different motivations is clearly supported by the participation of governments and EU institutions that are motivated differently to engage in litigation.

In the case of Denmark and Sweden, litigation was most likely by the implied clash between the Commission's practice to deny access to documents and the Scandinavian culture of transparency. In Scandinavia's culture of open government, transparency through public access to documents is a fundamental right of citizens that improves the political system's accountability and is part of these countries' constitutional, political, and cultural heritage (Grønbech-Jensen 1998). There have regularly been judicial conflicts between private actors and EU institutions about transparency and public access to EU documents where Scandinavian countries joined the dispute in favour of the litigant (e.g. T-84/03, T-174/95, T-14/98, T-111/07, T-250/08, T-362/08, T-436/09, or T-306/12). Against the background of strong national policies and a culture that favours transparency, the involvement of Denmark and Sweden in the annulment case is clearly the result of an ideological motivation for litigation.

Similarly, the active role of these governments is also due to these countries' history as outspoken critics of the EU's tobacco policy approach, which differentiates strongly between tobacco products. Sweden in particular has been willing to lobby at the EU level for the abolishment of the ban on smus, a moist powder tobacco that is placed under the upper lip and enjoys a high popularity in Sweden. Sweden even negotiated an opt-out from the smus ban when joining the EU. 
Without the opt-out, the referendum on EU integration would probably not have passed (Haydon 2012). To avoid distortions, all tobacco products-smoking and non-smoking tobacco-should be treated equally in the internal market, the Swedish government argued, according to Tobacco Tactics, a platform provided by the Tobacco Control Research Group at the University of Bath, which monitors the tobacco industry and charts its influence on public health, scientific research, and policy regulation (Tobacco Tactics 2017). Treating non-smoking tobacco more strictly than smoking tobacco was not seen to be fair or proportionate. Whether in this case, Scandinavian litigation was motivated by the willingness to send a signal of political trust worthiness to (snus-affine) electorates and Swedish Match (one of the world's largest producers of smokeless tobacco products), or by a willingness to voice Scandinavia's ideological preferences for transparent bureaucracy, their involvement in the conflict supports our point. Status quo disruption, even at the scale of comitology regulation, can trigger reactions from different kinds of actors based on different kinds of motivations, ultimately leading to complex judicial configurations.

While it seems fair to argue that Denmark and Sweden had motives that went beyond a mere financial interest in the case, this claim becomes even clearer for the participation of the European data protection supervisor. While the role of this actor is generally to ensure EU's institutions compliance with the processing of individual information and data protection rights of EU citizens, it also joined the case on the side of British American Tobacco. Essentially, the Commission justified the denial of the document request with a reference to the need to protect the identity of member state delegations in order to ensure frank and open discussions in committee. In the attempt to still flesh out his role, the European Data Protection Supervisor joined this case to have the Court confirm its general stake not only when personal data are processed but in all cases that involve data processing (Hofmann et al. 2011, 744). Its motivation was thus related to an attempt to establish the scope of his competences.

Overall, the case illustrates (1) how institutional turbulence can be created by challenges to the policy status quo of a minor magnitude than treaty modifications, and (2) that at such critical policy junctures, conflicts often attract multiple actors for different motivations because the multidimensional character of the challenged equilibrium creates multiple incentives to litigate. 


\section{Spanish Coal Case (T-57/11)}

That multidimensional motivations trigger complex litigant configurations becomes even clearer in case T-57/11 that dealt with Spanish coal subsidies. The conflict in the Spanish coal and energy sector emerged when the Spanish government decided in 2010 to protect domestic coal producers with subsidies for power plants using domestic as opposed to imported coal. The measure was adopted by the Socialist government in response to enduring protests by mine workers in Castile and León over unpaid wages (Abend 2010). While this measure strongly benefited power plants based on coal in the region of Castile and León, the regional government of Galicia opposed the subsidy since power plants in this area mainly ran on imported coal, gas, and oil. Consequently, the Galician government saw its power plants as falling victim to discrimination by this subsidy.

While the Spanish subsidy had challenged the status quo arrangements in local energy industries, the Commission consolidated this threat with its decision to authorize the subsidy as compatible with the internal market. The measure represented a clear change in Spain's energy policy. While Spain had been called a poster child for clean energy by Greenpeace, the environmental interest group decried that 'this success story is now under threat' as the 'Spanish government is retroactively changing the rules and cutting back on support for renewables' while at the same time increasing subsidies for its domestic coal industry (Simons 2014).

It is thus relatively easy to see that the resulting institutional turbulence comprised multiple dimensions. First, the Spanish measure, together with the Commission's decision to authorize it, comprised a clear financial dimension, since power plants feared for their revenue, and an environmental (ideological) dimension, since environmental interest groups decried the renewed subsidies for the coal sector. Furthermore, the measure was a threat to the Galician energy sector for benefitting the region of Castile and León as its competitor. There, the population and the mayors of the cities related to the Galician energy sector were very concerned and expected the Galician government to react in order to protect the local economy and Galician workers (MIN_GA_3).

These additional motivations were clearly reflected by the complexity of the litigant structure, which included, in this case, the Commission and the government of Spain, two private operators of coal-operated power 
plants, the regional government of Castile and León, and the Spanish National Association of Mining Companies on the defendant side. On the applicant side, the private power plant operator Castelnou Energia SL, which felt that the subsidy distorted competition in the energy sector, was supported by the environmental interest groupGreenpeace in its attack on the Commission's authorization (Abend 2010). The Galician government attempted to join the conflict in support of Castelnou Energia SL, but the General Court rejected its demand because Galicia, as a non-privileged applicant, was lacking legitimacy to litigate against the Commission's authorization (MIN_GA_3, LAW_1).

This conflict emerged in response to a change in EU policy that altered the path of national energy policy and put the Spanish energy policy at a critical juncture. This triggered responses by actors acting upon multiple motivations. Specifically, the case entailed a fair amount of legal uncertainty that encouraged different actors to join the case. This legal uncertainty resulted not only from the unusual form in which the subsidy was granted. While a simple subsidy payment would have had little prospect of sustaining a legal challenge, the Spanish government introduced an obligation to produce energy for power plants using Spanish coal to ensure a stable electricity supply and reduce Spain's dependence on energy imports. Consequently, the Spanish government justified the subsidy by referring to exemptions allowed by EU competition policy for services of general economic interest, which the power plants would provide. In exchange for this service of general economic interest, power plants would receive a financial compensation. More importantly, since no legislation or case law existed on this specific question, the Court's position was rather unclear as to how far the Commission would have to go in examining state aid. Would it be enough to examine its compatibility with state aid rules? Or would its coherence with other EU policies, such as climate change legislation and electricity market legislation, have to be taken into consideration as well (Cisnal de Ugarte and Di Masi 2016, 21)? One clear indicator for the high level of uncertainty connected to the legal case was the great interest with which the legal community observed the proceedings. The Court's position on the inherent connection between state aid law and EU environmental law was seen to be unclear and was awaited with some excitement. Would state aid measures that did not pursue environmental objectives have to take EU rules on the protection of the environment 
into account anyways? No matter what the Court's answer would be, this answer would represent a critical juncture in the EU's state aid law (Cisnal de Ugarte and Di Masi 2016, 21).

\section{CONCLUSION}

While litigant configurations are typically treated as exogenous factors that are merely analysed for their impacts on judicial decisions, in this chapter we explored the conditions under which different litigant configurations emerge. While we highlighted the variety of litigant configurations in the context of annulment litigation, we proposed that a distinction between simple ( $1 \mathrm{v} .1$ ) configurations and complex configurations (all other constellations) represents an analytically rather powerful difference. This chapter constitutes a first step towards supporting this claim by highlighting that such complex litigant configurations (of whatever form) emerge more often in situations of institutional turbulence.

Obviously, legal standing rights of non-privileged actor types can be effective obstacles for the emergence of complex litigant configurations. Nevertheless, we observe an empirically non-trivial number of such complex litigant configurations; particularly in times of institutional turbulence. Institutional turbulence shakes up established equilibria and thereby increases the stakes for policy conflicts for a wide variety of actors. Simply put, the question of how conflicts in such a situation of turbulence are resolved is very important for financial, ideological, power-related, and political trust reasons. Thereby, turbulence increases the chances of complex litigant configurations because court rulings have greater implications on more diverse respects on a greater number of actors. Moreover, turbulence comes with legal uncertainty. After all, the Court has not had the chance to interpret the new rules that created the turbulence in the first place. This acts as a further incentive to not shy away from annulment litigation. These empirical conditions that promote the emergence of annulment conflicts with complex litigant configurations also affects patterns of legal outcomes of court proceedings. We assess these in the Chapter 7.

\section{Cases Cited}

See Table 6.6. 
Table 6.6 Cases cited in this chapter

\begin{tabular}{|c|c|}
\hline C-114/12 & $\begin{array}{l}\text { Judgment of } 4 \text { September 2014, Commission v. Council, C-114/12, } \\
\text { EU:C:2014:2151 }\end{array}$ \\
\hline $\mathrm{T}-111 / 00$ & $\begin{array}{l}\text { Judgment of } 10 \text { October 2001, British American Tobacco p. Commission, } \\
\text { T-111/00, EU:T:2001:250 }\end{array}$ \\
\hline $\mathrm{T}-84 / 03$ & $\begin{array}{l}\text { Judgment of } 23 \text { November 2004, Turco v. Council, T-84/03, } \\
\text { EU:T:2004:339 }\end{array}$ \\
\hline $\mathrm{T}-170 / 03$ & $\begin{array}{l}\text { Order of } 6 \text { September 2010, British American Tobacco v. Commission, } \\
\text { EU:T:2010:348 }\end{array}$ \\
\hline $\mathrm{T}-174 / 95$ & $\begin{array}{l}\text { Judgment of } 17 \text { June 1998, Tidningen Journalisten v. Council, } \\
\text { EU:T:1998:127 }\end{array}$ \\
\hline $\mathrm{T}-14 / 98$ & Judgment of 19 July 1999, Hautala v. Council, T-14/98, EU:T:1999:157 \\
\hline $\mathrm{T}-111 / 07$ & $\begin{array}{l}\text { Judgment of } 7 \text { July 2010, Agrofert Holding v. Commission, T-111/07, } \\
\text { EU:T:2010:285 }\end{array}$ \\
\hline $\mathrm{T}-250 / 08$ & $\begin{array}{l}\text { Judgment of } 24 \text { May 2011, Batchelor v. Commission, T-250/08, } \\
\text { EU:T:2011:236 }\end{array}$ \\
\hline $\mathrm{T}-362 / 08$ & $\begin{array}{l}\text { Judgment of } 13 \text { January 2011, IFAW v. Commission, T-362/08, } \\
\text { EU:T:2011:6 }\end{array}$ \\
\hline $\mathrm{T}-436 / 09$ & Judgment of 26 October 2011, Dufour v. ECB, T-436/09, EU:T:2010:89 \\
\hline $\mathrm{T}-57 / 11$ & $\begin{array}{l}\text { Judgment of } 3 \text { December 2014, Castelnou Energia v. Commission, } \\
\text { T-57/11, EU:T:2014:1021 }\end{array}$ \\
\hline $\mathrm{T}-306 / 12$ & $\begin{array}{l}\text { Judgment of } 25 \text { September 2014, Spirlea v. Commission, T-306/12, } \\
\text { EU:T:2014:816 }\end{array}$ \\
\hline
\end{tabular}

\section{Notes}

1. The amici curiae concept refers to a professional person or organization that is not a party to a particular litigation but that has the permission of the Court to advise it in respect to some matter of law that directly affects the case in question.

2. Commission decision of 9 November 2005 on the state aid that the Federal Republic of Germany has implemented for the introduction of digital terrestrial television (DVB-T) in Berlin-Brandenburg (notified under document number C [2005] 3903). Official Journal of the European Communities, 2006 (L 200), p. 14.

3. Specifically, the Commission based its decision on the concept of market failure, a practice it announced in its State Aid Action Plan and became subjectable to judicial review when it was used in a regular state aid decision (Adam 2016).

4. Council Directive 93/83/EEC of 27 September 1993 on the coordination of certain rules concerning copyright and rights related to copyright applicable to satellite broadcasting and cable retransmission, Official Journal L 248, 6.10.1993, pp. 15-21. 
5. Council Directive 93/83/EEC of 27 September 1993 on the coordination of certain rules concerning copyright and rights related to copyright applicable to satellite broadcasting and cable retransmission, Official Journal L 248, 6.10.1993, pp. 15-21.

6. Commission Regulation (EEC) No. 3311/86.

7. Council Directive $92 / 12 /$ EEC of 25 February 1992 on the general arrangements for products subject to excise duty and on the holding, movement and monitoring of such products, Official Journal L 76, 23.3.1992, pp. 1-13.

8. On 6 December 1993, the Commission and the Council approved a common code of conduct concerning public access to Council and Commission documents (OJ 1993 L 340, p. 41, hereinafter 'the code of conduct').

\section{REFERENCES}

Abend, L. (2010). Spain's coal miners fight for the right to keep digging. Time. http://content.time.com/time/world/article/0,8599,2020555,00.html. Accessed 22 August 2017.

Adam, C. (2016). The politics of judicial review: Supranational administrative acts and judicialized compliance conflict in the EU. Basingstoke, UK: Palgrave Macmillan.

Andersen, E. A. (2005). Out of the closets and into the courts legal opportunity structure and gay rights litigation. Ann Arbor: The University of Michigan Press.

Ansell, C. K., Trondal, J., \& Øgård, M. (Eds.). (2017). Governance in turbulent times. Oxford, UK: Oxford University Press.

Bauer, M. W., \& Hartlapp, M. (2010). Much ado about money and how to spend it! Analysing 40 years of annulment cases against the European Union Commission. European Journal of Political Research, 49, 202-222.

British American Tobacco. (2014). Science-tobacco blend. http://www. bat-science.com/groupms/sites/BAT_9GVJXS.nsf/vwPagesWebLive/ DO7AXG65. Accessed 22 August 2017.

Burns, T., \& Stalker, G. M. (1961). The management of innovation. London: Tavistock.

Cameron, K. S., Kim, M. U., \& Whetten, D. A. (1987). Organizational effects of decline and turbulence. Administrative Science Quarterly, 32(2), 222-240.

Canadian Coalition for Action on Tobacco. (2004). A win-win: Enhancing public health and public revenue-Recommendations to increase tobacco taxes submitted to the minister of finance. http://www.smoke-free.ca/pdf_l/ 2004taxreport.pdf. Accessed 7 December 2017.

Carrubba, C. J., Gabel, M., \& Hankla, C. (2008). Judicial behavior under political constraints: Evidence from the European Court of Justice. American Political Science Review, 102(4), 435-452. 
Carrubba, C. J., Gabel, M., \& Hankla, C. (2012). Understanding the role of the European Court of Justice in European integration. American Political Science Review, 106(1), 214-224.

Cisnal De Ugarte, S., \& Di Masi, L. (2016). The European antitrust review 2016. Crowell. https://www.crowell.com/files/European-Union-Energy.pdf. Accessed 22 August 2017.

Court of Justice of the European Union. (2001). Judgment of the Court of First Instance of 10 October 2001 on British American Tobacco International Investments Ltd. v. Commission in Case T-111/00. European Court Reports 2001(II), 02997.

Court of Justice of the European Union. (2014). Judgment of the Court of 4 September 2014 in European Commission v. Council of the European Union Case C-114/12. Official Journal of the European Union 57, C 395.

Geerts, T. (2012). Partnering with Belgian news publishers. Google Europe Blog. https://europe.googleblog.com/2012/12/partnering-with-belgian-newspublishers.html. Accessed 22 August 2017.

Glenn, H. (1999). Paths to justice: What people do and think about going to law. Oxford, UK: Hart Publishing.

Grønbech-Jensen, C. (1998). The Scandinavian tradition of open government and the European Union: Problems of compatibility? Journal of European Public Policy, 5(1), 185-199.

Hall, P. A., \& Taylor, R. C. R. (1996). Political science and the three new institutionalisms. Political Studies, 44, 936-957.

Haydon, P. (2012, October 29). In Sweden, smokers have another optionSnus. The Guardian. https://www.theguardian.com/commentisfree/2012/ oct $/ 29 /$ sweden-smokers-option-snus.

Hofmann, H. C. H., Rowe, G. C., \& Türk, A. H. (2011). Administrative law and policy of the European Union. Oxford, UK: Oxford University Press.

Larsson, O., \& Naurin, D. (2016). Judicial independence and political uncertainty: Assessing the effect of legislative override on the European Court of Justice. International Organization, 70(2), 377-408.

Miller, D. (2013). TRP starts DIET plant. Tobacco Reporter. http://www.tobaccoreporter.com/2013/08/trp-starts-diet-plant/. Accessed 7 December 2017.

Pedersen, H. S., Floristean, A., Iseppi, L., Dawkins, R., Smith, C., Morup, C., et al. (2012). Study on the measuring and reducing of administrative costs for economic operators and tax authorities and obtaining in parallel a higher level of compliance and security in imposing excise duties on tobacco products. http:// ec.europa.eu/smart-regulation/evaluation/search/download.do?documentId $=11702485$. Accessed 7 December 2017.

Rosati, E. (2016). Neighbouring rights for publishers: Are national (possible) EU initiatives lawful? International Review of Intellectual Property and Competition Law, 47(5), 569-594. 
Schmidt, S. K. (2012). Who cares about nationality? The path-dependent case law of the ECJ from goods to citizens. Journal of European Public Policy, 19(1), 8-24. https://doi.org/10.1080/13501763.2012.632122.

Sheehan, R. S., Mishler, W., \& Songer, D. R. (1992). Ideology, status, and the differential success of direct parties before the Supreme Court. American Political Science Review, 86(2), 464-471. https://doi.org/10.2307/ 1964234.

Simons, D. (2014). Should the European Commission wear green goggles more often? Greenpeace International. http://www.greenpeace.org/international/en/news/Blogs/makingwaves/Castelnou-Energia-v-Commission/ blog/50868/. Accessed 22 August 2017.

Terpan, F. (2015). Soft law in the European Union-The changing nature of EU Law. European Law Journal, 21(1), 68-96. https://doi.org/10.1111/ eulj.12090.

Tobacco Tactics. (2017). Snus: EU ban on snus sales. University of Bath. http:// www.tobaccotactics.org/index.php/Snus:_EU_Ban_on_Snus_Sales. Accessed 22 August 2017.

Trondal, J., \& Bauer, M. W. (2017). Conceptualizing the European multilevel administrative order: Capturing variation in the European administrative system. European Political Science Review, 9(1), 73-94.

Vanhala, L. (2011). Making rights a reality? Disability rights activists and legal mobilization. Cambridge, UK: Cambridge University Press.

Woods, L., \& Peers, S. (2014). Copyright: Anything left of member states external competence? EU Law Analysis. http://eulawanalysis.blogspot.de/2014/09/ copyright-anything-left-of-member.html. Accessed 22 August 2017.

Open Access This chapter is licensed under the terms of the Creative Commons Attribution 4.0 International License (http://creativecommons.org/licenses/ by $/ 4.0 /$ ), which permits use, sharing, adaptation, distribution and reproduction in any medium or format, as long as you give appropriate credit to the original author(s) and the source, provide a link to the Creative Commons license and indicate if changes were made.

The images or other third party material in this chapter are included in the chapter's Creative Commons license, unless indicated otherwise in a credit line to the material. If material is not included in the chapter's Creative Commons license and your intended use is not permitted by statutory regulation or exceeds the permitted use, you will need to obtain permission directly from the copyright holder.

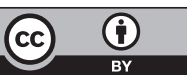

